\title{
Evaluating The QUALity OF OPTIONAL ExCURSIONS Provided by Egyptian Travel Agents in Hurghada
}

\author{
Ahmed BarakaAt \\ Faculty of TOURISM ANd Hotels, Minia University, Egypt \\ Noha Abou ElGheit \\ FACUlTY OF TOURISM AND HOTELS, SOUTH VAlLey UNIVERSITY, LUXOR BRANCH, \\ EGYPT \\ AyMAN KASEM \\ FACULTY OF TOURISM AND HOTELS, MINIA UNIVERSITY, EgYPT \\ Sabreen G. Abd Eljalil \\ Faculty of TOURISM AND Hotels, SOUTH Valley UNIVERSity, LUXor Branch, \\ EGYPT
}

\begin{abstract}
Optional excursion is now one of the main products in Egypt and has become a niche market to the country. There are several types of optional excursions in Red Sea Governorate among which diving, snorkeling safari tours, beach buggy, etc. The purpose of this paper is to assess the optional excursions in Hurghada. This paper clarified that there is a notable gap between the expectations and perceptions of tourists towards the optional tours. Quantitative approach based on questionnaires that directed to tourists in Hurghada. The results indicated that snorkeling is the most popular tour followed by diving then the safari tours come next. The lowest rank of optional tours was the water sports activities. Based on the results, some recommendations were suggested to improve the quality of optional excursions to reach the customer satisfaction.
\end{abstract}

KeYwORDS: Hurghada, Optional excursions, Service quality, Travel agents.

\section{INTRODUCTION}

Travel agencies are considered major actors in tourism industry development. They are considered as an intermediate channel between customers and service providers. They also promote the products 
presented by holiday suppliers like hotels, sightseeing operators, excursions, etc (Chang, 2008).

They play an important role in offering optional excursion as it has an incredible energy which impact and direct tourist demand. They are not just mediators but also they act an interface amongst supply and diverse segments of demand (Pastiu, et al., 2014). Mancini (2012) and Jafari (2002) explained optional excursions as a short trip that is not included in the price of the tour.

Tourists can purchase it during their trip and thus it increases the income of the tour providers. Optional excursions are added to increase the attractiveness of the accommodation product with the aim to attract guests in the first place and possibly induce them to stay longer and spend more. Excursions can also be the main appeal of the vacation where accommodation itself plays a secondary role such as many tourists visit Red Sea mandatory for diving (Ashley, 2005).

This paper provides an evaluation to the quality of optional excursions in Hurghada city by employing SERVQUAL instrument that is used to measure a service quality based on the difference between consumers' expectation and perception of service. Thus, this paper attempts to fulfill the following objectives:

- Identifying the OptionalExcursions in Hurghada city.

- Comparing the average gap score between expectations and perceptions of optional excursion.

- Assessing the quality of optional excursions in Hurghada.

- Helping travel agents and optional excursion managers to point out the areas of weakness that has to be strengthened.

\section{LITERATURE REVIEW}

\section{HURghada Optional ExCURSIONS}

Hurghada is considered an ideal tourist destination as it has several natural and man-made attractions. Natural attractions are represented in moderate climate all over the year and good visibility of water. The close proximity to the Equator and the calmness of the water increases light penetration. Thus, it is suitable for the growth of underwater wildlife, plants and coral reefs (ETA, 2015; Red Sea Governorate, 2015). Red Sea provides world class sites for conducting both land and marine recreational excursions (USAID, 2004).

\section{LAND OPTIONAL EXCURSIONS}

Optional land excursions in Hurghada are planned to give the tourists the opportunity to discover the desert whether independently or in organized 
tours, from these land excursions: Bedouin tents and desert safari, birdwatching, horse and camel riding, quad biking and hiking (ETA, 2015).

\section{BEDOUIN TENTS AND DESERT SAFARI}

The word "Safari" originates from Swahili and means "journey". When used in English or German in colonial times, it referred to hunting expeditions.

Currently, the term safari is most often used as a synonym for wildlife watching tourism and refers to tourism activities taking place mainly in protected areas that offers the opportunity to observe and photograph wild animals in their natural habitats. The classic form of safari entails observing wildlife from four-wheel drive vehicles and staying in tented safari camps or lodges. Newly emerging forms of safari include trekking, kayaking or camel safaris (UNWTO, 2014). Many tourists are interested in spending just a few hours in the desert to escape away from beachside resorts and hotels.

Visitors go to desert by four wheel drive vehicles and $4 \times 4$ "quad" bikes to safari stations. Each station consists of a central area of tourist service buildings including welcome halls, an entertainment enclosure, a kitchen, and several toilets. Most stations have a small grocery store, operated by a Bedouin to serve tourists (Hobbs \&Tsunemi, 2007).

Desert safari in Egypt can be explained as a tour by jeep to the Egyptian desert where tourists can stay at very primitive tents and have dinner with Bedouin tribes. Tourists also can enjoy many activities in the Egyptian desert such as quad biking, camel riding, looking at desert gypsies' life, taking photos, listening to music, dancing and watching sun set (Boersma, 2010).

\section{BIRD-WATCHING}

Viewing birds in their natural habitat is known as bird-watching or avitourism (Moss, 2004). Depending on infrastructure and safety, bird watching tourists often travel in organized tours or independently. Alternatively, they may engage local guides upon arrival in a destination. This practice has provided some less developed regions with diverse avifauna and opportunities to develop low-impact tourism and increase capacity building in remote communities.

This often coincides with the opportunity for locals to be trained as guides by international bird conservation organizations like (Bird sanctuaries, American bird conservancy....etc.) thus promoting sustainable development and conservation in those destinations (Biggs et al, 2011). 


\section{HORSE AND CAMEL RIDING}

The camel is considered not only a symbol of Arabia but also major tourist attraction. Camel rides are part of some tours and desert safari. Tour operators and hotels can also arrange camel rides separately (Horner and Swarbrook, 2004).

\section{QUAD BIKING}

This term refers to four wheel motorbikes which can be driven easily. They are widely available at all Red Sea destinations for inspiring rides in the Eastern Desert of Egypt. Tourist can rent a quad-bike at sunset in the Western Desertoases to ride freely through the barren desert landscape. Tourist can also book his ride through his hotel or through a trusted safari operator; they will provide him with a guide who will lead his way through the unknown parts of the desert. Quad biking is described as exciting excursion with friends and heading off to the desert for a thrilling ride (ETA, 2015).

\section{HIKING}

Hiking means to go on an extended walk for pleasure or exercise. It is an outdoor activity which is considered the best way to see the amazing nature. Hikers often seek for beautiful natural environments to walk beside (Jordan, 2000).

\section{MARINE OPTIONAL EXCURSIONS DIVING}

According to Musa and Dimmock (2013) diving is a popular form of marine leisure activities among tourists. Previously, it is considered as a hard adventure activity but it has now begun to be accepted as a soft adventure one. This change is a result of continuous invention of more efficient and safer equipment. It has grown rapidly to attract millions of people who are interested in sea and recreational activities. Red sea is an excellent choice for people who enjoy diving as it has warm clear water full of marine life. Visibility of underwater life is incredible as it gives photographers suitable conditions to obtain wonderful shots (Buckles, 2007).

\section{SNORKELING}

It is one of the easiest, safest and most pleasant ways to explore the underwater world. It is a swimming on the surface of the water with the masks, fins and snorkelers (PADI, 2013). The Egyptian Red Sea is characterized by magnificent sandy beaches, crystal clear water and incredible coral heads. 
The area is full of colorful fish species in addition to dolphins. Tourists who swim with those dolphins consider themselves lucky. All these reasons have made the snorkeling in Hurghada unique (ETA, 2015).

\section{WATER SPORTS}

Water sports have been around for centuries. Ancient Egyptian for example loved rowing, and held several row competitions. Recently, technology has allowed water sports to advance even further. Now people can use specially designed boats, boards, skis and other water crafts to enter a new frontier (Butler, 2017).Various organizations and authors mentioned that water sports included kite surfing, wind surfing, power boat racing, water skiing, wake boarding and jet skiing (Jennings, 2007).

\section{Cruise ShIPS}

Cruise visits seem to be considerable source of economic development for coastal communities. Moreover, cruise ships arrive early in the morning in a port and leave between late afternoon and midnight. This time gives passengers an opportunity to undertake recreational activities like: diving, fishing, rafting and hiking. They also can take shore tours, shop and explore the port community (Manning, 2006).

\section{SUBMARINE AND GLASS BOATS}

Submarine in a dictionary is a vessel that can be submerged and navigated under water (Jones, 2008). Friedland et al, (2010) illustrated that submarine tour is the perfect family adventure. It allows tourists to get close to coral reefs, fish, amazing rock formations, shipwreck and other unique sea creatures. Passengers of any age and physical condition can enjoy a comfortable and safe experience.

\section{DOLPHIN SHOW}

People love dolphins than any other wild animal. Facilities providing the public with an opportunity to watch and interact with dolphins in captivity have become increasingly widespread over the past twenty years. Cruise ship passengers and other tourists can now swim with dolphinsat more than thirty marine attractions throughout the Caribbean, Spain, the Algarve, and the Canary Islands as well as in Egypt, Middle East and Asia (Curtin \& Wilkes, 2007). The Red sea in South Egypt is considered one of the few places in the world where wild dolphins have been known to play with divers in the water (Buckles, 2007).

\section{SERVICE QUALITY OF RED SEA ExCURSION}

Service quality is being the main driving force of service providers to build the competitive advantages as well as positioning in market. 
Moreover, keeping the existing customers as well as attracting new ones (Kandampully, 2000; Yoon\&Ekinci, 2003; Kvist\&Klefsjo, 2006).

The growing recognition of the importance of such quality in service industries has been driven by the realization that high service quality results in positive behavioral intentions as well as greater market share and profitability (Caruana, 2002). Servqual model was used to measure the service quality of the Red sea optional tours based on the difference between consumers ${ }^{\text {ee }}$ expectations and experiences of service.

\section{Research Methodology}

Quantitative approach based on a questionnaire that was developed and directed to tourists while they were practicing optional excursions in Hurghada to achieve the aim of this study. The questionnaire consists of three main parts. Part one dealt with the socio-demographic data of the respondents. Part two is based on the customers' expectations of the service quality on a 5-point Likert scale, ranging from "strongly disagree" which scored 1 to "strongly agree" which scored 5. Part three was to assess the customers' perceptions of the service quality on the same 5point Likert scale. The field study was applied in the Red Sea Governorate in Hurghada city. It is considered an important tourist destination because it has a variety of marine activities and land excursions which made it attractive for large numbers of tourists from all over the world. The survey was conducted in May, June and July 2017.

The random sample size was 450 tourists. Only 216 responses were valid resulting in a $54 \%$ percent response rate. The population of this study was represented at random sample from tourists who practice optional excursions in Hurghada. Descriptive statistical analysis was used to investigate the socio demographic profile of the respondents. Paired ttests were conducted to assess the significance of differences between the two means of expectations and perceptions at a significance level of $p<$ 0.05 . The principle component analysis was conducted to reduce the 26 service attributes into a set of simplified dimensions; these attributes were used by Lam \& Zhang (1999) and Shahin (2004).

\section{RESULTS AND DISCUSSION}

Personal demographic characteristics were presented by using frequencies and percentages for all variables, including gender, age, marital status, income and nationalities. The questionnaire successfully captured a fairly even representation of gender with $52.8 \%$ of respondentswere female and $47.2 \%$ were male.Based on age the main respondents in this research are in the age group (21-30) years old which shows a percentage of $36.1 \%$. The second largest age group is the group (31-40) years; this age group 
shows a percentage of $25.5 \%$. It is followed by the age group (51- 60) years old that shows a percentage of $15.7 \%$. Next age group is (41-50) years that show a percentage of $12.5 \%$.

A small proportion of respondents are in the age group (younger than 20 years) old that shows a percentage of $7.9 \%$. The smallest group is the group with people that are (older than 61) years and this group shows a percentage of $2.63 \%$.

Table 1 show that $39.8 \%$ of respondentsreporting'married'. It is followed by 'single' that shows a percentage of $32.4 \%$. The smallest group is 'others' that show a percentage of $27.8 \%$. Regarding the monthly income, the majority of the respondents were with income group (less than 1000 dollars), that shows a percentage of $38.4 \%$. The second largest income group is the group between (1001- 2000 dollars), which shows a percentage of $25 \%$. On the other hand, there were $20.4 \%$ of respondents belong to the income group (between 2001 and 3000 dollars). This is followed by the income group (between 3001 and 4000 dollars), which shows a percentage of $10.5 \%$. The last group was the income group more than 4000 dollars that shows a percentage of $5.6 \%$.

The majority of those who participated in the survey were citizens of European Union member countries. It is clear that $22.2 \%$ from visitors surveyed were German. British citizens ranked the second with a percentage of $17.6 \%$. Ukraine citizens rounded out the third with a percentage of $16.7 \%$. Belgian citizens represent a percentage of $15.3 \%$. It's followed by Poland that shows a percentage of $14.4 \%$. On the other hand, Belarusians represent $6.9 \%$ of respondents. The smallest portions of visitors were from Czech that shows a percentage of $3.2 \%$. The other nationalities represent $3.7 \%$.

Table1: Demographic characteristics of respondents

\begin{tabular}{|c|c|c|}
\hline \multicolumn{1}{|c|}{ Demographic Characteristics } & Percentage \\
\hline Gender & Male & $47.2 \%$ \\
\hline \multirow{3}{*}{ Age } & Female & $52.8 \%$ \\
\hline & Younger than 20 years & $7.9 \%$ \\
\hline 21-30 years old & $36.1 \%$ \\
\hline 31-40 years old & $25.5 \%$ \\
\hline 41-50 years old & $12.5 \%$ \\
\hline 51-60 years old & $15.7 \%$ \\
\hline & Older than60 years old & $2.3 \%$ \\
\hline & Single & $32.4 \%$ \\
\hline
\end{tabular}




\begin{tabular}{|c|c|c|}
\hline \multicolumn{1}{|c|}{ Demographic Characteristics } & Percentage \\
\hline Marital status & Married & $39.8 \%$ \\
\cline { 2 - 3 } Monthly income & Others & $27.8 \%$ \\
\cline { 2 - 3 } & less 1000 dollar & $38.4 \%$ \\
\cline { 2 - 3 } & 1000-2000 dollars & $25.0 \%$ \\
\hline 2000-3000 dollars & $20.4 \%$ \\
\hline 3000-4000 dollars & $10.6 \%$ \\
\hline more 4000 dollars & $5.6 \%$ \\
\hline German & $22.2 \%$ \\
\hline & British & $17.6 \%$ \\
\hline Ukraine & $16.7 \%$ \\
\hline Belgian & $15.3 \%$ \\
\hline & Poland & $14.4 \%$ \\
\hline & Belarusian & $6.9 \%$ \\
\hline & Czech & $3.2 \%$ \\
\hline & Others & $3.7 \%$ \\
\hline
\end{tabular}

\section{TYPES OF OPTIONAL EXCURSIONS IN HURGHADA}

Table 2 shows the various types of optional tours in Hurghada. The variable that yielded the highest mean in terms of popular excursions is snorkeling by $22.7 \%$ of respondents. It is followed by $19.9 \%$ of respondents who practiced diving then jeep safari which represents 19.4\% of respondents. Beach buggy comes next which ranked fourth by a percentage of $18.5 \%$ of respondents. The last one was water sports which represent $18.1 \%$ of respondents.

Table 2: Types of optional excursions in Hurghada Red Sea

\begin{tabular}{|c|c|c|c|c|}
\hline Types & Frequency & Percent & Valid Percent & Cumulative Percent \\
\hline Diving & 43 & 19.9 & 19.9 & 19.9 \\
\hline Snorkeling & 49 & 22.7 & 22.7 & 42.6 \\
\hline Water sports & 39 & 18.1 & 18.1 & 60.6 \\
\hline Beach buggy & 40 & 18.5 & 18.5 & 79.2 \\
\hline Jeep safari & 42 & 19.4 & 19.4 & 98.6 \\
\hline Others & 3 & 1.4 & 1.4 & 100.0 \\
\hline Total & 216 & 100.0 & 100.0 & \\
\hline
\end{tabular}




\section{EXPECTATIONS AND PERCEPTIONS OF SERVICE QUALITY AND GAP VALUES}

Table 3 shows the perceptions, expectations, gap means and $\mathrm{T}$ value regarding the differences between perceptions of optional excursions quality and expectations. The results showed that customers had not got high expectations of optional excursions as the highest mean of expectation was for staff in travel agency who are always willing to help excursionists $($ Mean $=4.40)$, followed by staff in travel agency who are experienced and have the knowledge to answer excursionist questions (mean= 4.39). Contrast to these results, excursionist had not got low expectations of optional excursions as the lowest mean of expectation was forthe physical facilities and materials associated with optional excursion (such as pamphlets or statements) that are available and visually appealing (mean=4.26). The attributes that yielded the highest mean of optional excursions perceptions was for staff who had good appearance during optional excursion (mean=3.58).

The lowest mean of perceptions was forstaff in travel agency who were consistently courteous with excursionist (mean score $=3.34$ ). As shown in table 3, expectation scores of optional excursions in this study were higher than the perception scores indicating that each service attribute suffered a service quality shortfall. The largest gap mean was found for staff in travel agency who were consistently courteous with excursionist (Gap mean= -94) and travel agency had staff who give excursionist personal attention (Gap mean-94). The overall optional excursion perceived quality is low (-4.28) meaning the level of quality that the excursionists receive is lower than what they expect.

Table 3 compares the average gap score between expectations and perceptions of optional excursion .Regarding the differences between perceptions of received service quality and expectations. The more perceptions are close to expectations, the higher the perceived level of quality. 


\section{Table 3 Difference between expectations and perceptions of optional excursion}

\begin{tabular}{|c|c|c|c|c|c|c|c|c|}
\hline \multicolumn{2}{|r|}{ Attributes } & Mean & SD & Mean & SD & Gap & Rank & T value \\
\hline 1 & $\begin{array}{l}\text { The equipments are up to date and of modern } \\
\text { looking. }\end{array}$ & 3.48 & 1.149 & 4.35 & .787 & -.87 & 6 & $-11.123-* *$ \\
\hline 2 & $\begin{array}{l}\text { The physical facilities are available and visually } \\
\text { appealing. }\end{array}$ & 3.44 & 1.136 & 4.26 & .828 & -.82 & 10 & $-10.828-* *$ \\
\hline 3 & $\begin{array}{l}\text { The equipments ensure safety and comfort for the } \\
\text { excursionist. }\end{array}$ & 3.47 & 1.165 & 4.31 & .772 & -.84 & 9 & $300-* *$ \\
\hline 4 & Staff of optional excursion are smart in appearance & 3.58 & 1.109 & 4.28 & .878 & -0.7 & 14 & $-9.144-* *$ \\
\hline 5 & $\begin{array}{l}\text { Travel agent implemented the promised excursion } \\
\text { program. }\end{array}$ & 3.53 & 1.128 & 4.34 & .820 & -.81 & 11 & $-10.449-* *$ \\
\hline 6 & $\begin{array}{l}\text { Travel agent implemented the excursion program } \\
\text { at the promised time. }\end{array}$ & 3.46 & 1.091 & 4.30 & .902 & -.84 & 9 & $-10.102-* *$ \\
\hline 7 & $\begin{array}{l}\text { Travel agent performed excursion program } \\
\text { accurately, dependably and right first time }\end{array}$ & 3.44 & 1.119 & 4.33 & .788 & -.89 & 4 & $-12.349-* *$ \\
\hline 8 & $\begin{array}{l}\text { Travel agents show a sincere interest in solving } \\
\text { problems. }\end{array}$ & 3.47 & 1.082 & 4.37 & .791 & -0.9 & 3 & $-13.763-* *$ \\
\hline 9 & Travel agent insist on error-free records & 3.41 & 1.117 & 4.27 & .798 & -.86 & 7 & $-12.380-* *$ \\
\hline 10 & $\begin{array}{l}\text { Staff in travel agency tell excursionist exactly } \\
\text { when excursion will be performed }\end{array}$ & 3.53 & 1.104 & 4.32 & .822 & -.79 & 12 & $-11.648-* *$ \\
\hline 11 & $\begin{array}{l}\text { Staff in travel agency give prompt service to } \\
\text { excursionist }\end{array}$ & 3.55 & 1.077 & 4.29 & .879 & -.74 & 13 & $-10.845-* *$ \\
\hline
\end{tabular}




\begin{tabular}{|c|c|c|c|c|c|c|c|c|}
\hline \multicolumn{2}{|r|}{ Attributes } & Mean & SD & Mean & SD & Gap & Rank & T value \\
\hline 12 & $\begin{array}{l}\text { Staff in travel agency are always willing to help } \\
\text { excursionist }\end{array}$ & 3.55 & 1.107 & 4.40 & .795 & -.85 & 8 & $-12.690-* *$ \\
\hline 13 & $\begin{array}{l}\text { Staff in travel agency were are not too busy to } \\
\text { respond to excursionist's requests }\end{array}$ & 3.47 & 1.169 & 4.36 & .770 & -.89 & 4 & $-12.197-* *$ \\
\hline 14 & $\begin{array}{l}\text { The behavior of Staff in travel agency instill } \\
\text { confidence in excursionist }\end{array}$ & 3.42 & 1.194 & 4.35 & .769 & -.93 & 2 & $-12.892-* *$ \\
\hline 15 & $\begin{array}{l}\text { Excursionists are feel safe in their dealings with } \\
\text { the travel agency }\end{array}$ & 3.49 & 1.133 & 4.38 & .804 & -.89 & 4 & $-12.382-* *$ \\
\hline 16 & $\begin{array}{l}\text { Staff in travel agency are consistently courteous } \\
\text { with excursionist }\end{array}$ & 3.34 & 1.229 & 4.28 & .846 & -.94 & 1 & $-10.980-* *$ \\
\hline 17 & $\begin{array}{l}\text { Staff in travel agency were experienced and had } \\
\text { the knowledge to answer excursionist questions }\end{array}$ & 3.49 & 1.145 & 4.39 & .732 & -0.9 & 3 & $-11.490-* *$ \\
\hline 18 & Travel agent give excursionist individual attention & 3.46 & 1.231 & 4.33 & .846 & -.87 & 6 & $-10.682-* *$ \\
\hline 19 & $\begin{array}{l}\text { Travel agency have operating hours convenient to } \\
\text { all excursionists }\end{array}$ & 3.41 & 1.174 & 4.28 & .867 & -.87 & 6 & -10.787-** \\
\hline 20 & $\begin{array}{l}\text { Travel agency have staff who give excursionist } \\
\text { personal service }\end{array}$ & 3.38 & 1.164 & 4.32 & .833 & -.94 & 1 & $-11.248-* *$ \\
\hline 21 & $\begin{array}{l}\text { Travel agency have the excursionist 's best } \\
\text { interests at heart }\end{array}$ & 3.45 & 1.211 & 4.29 & .813 & -.84 & 9 & $-10.653-* *$ \\
\hline 22 & $\begin{array}{l}\text { The staff of travel agency understand the specific } \\
\text { needs of their excursionists }\end{array}$ & 3.40 & 1.173 & 4.28 & .851 & -.88 & 5 & $-11.552-* *$ \\
\hline
\end{tabular}




\section{Notes:}

1. ** T-test two- tail with probability $<0.01$.

2. Customers' expectations and perceptions were measured on a 5poin Likert scale, $1=$ strongly disagree and 5 strongly agree.

3. A Gap mean is defined as perception mean - expectation mean.

4. SD: standard deviation.

\section{PERCEIVED QUALITY OF OPTIONAL EXCURSIONS DIMENSIONS}

The gap score analysis in table 4 enables us to find out how excursionists perceiveoptional excursions quality and try to identify what dimensions of optional excursions which had low quality. According to Parasuraman et al, (1985, p.48) the higher (more positive) the perception (P) minus expectation (E) score, the higher the perceived service quality.

\section{Assurance}

It was reported to have highest average gap score (-.91). The findings reveal that excursionists do not agree with the behavior of staff in travel agency who are consistently courteous with them, the behavior of staff in travel agency instill confidence in excursionist, staff are experienced and have the knowledge to answer excursionist questions. Excursionists of travel agency feel safe in dealings with their travel agencies especially in optional excursion.

\section{EMPATHY}

It had average gap score of (-.88). To this extend travel agents should give excursionists individual attention, operating hours should be convenient to excursionists, staff of travel agents should give excursionists personal service, they should understand their specific needs and also should have excursionist's best interests at heart.

\section{RELIABILITY}

Reliability obtained average gap score of (-.86).which means that travel agents in Hurghada are expected to be more reliablein implementing the promised excursion program and at the promised time. Travel agents perform optional excursion program accurately, dependably from the first time when excursionist has problem and also they have to show sincere interest in solving it.

\section{RESPONSIVENESS}

Responsiveness obtained average gap score of (-.82). Excursionists expect more from staff of travel agents in Hurghada who should tell them exactly when optional excursion will be performed; give prompt service and always willing to help them. 


\section{TANGIBLES}

It has average gap score of (-.81). Excursionists are not agreeing with the optional excursion quality level. The equipments should be up to date and with modern looking. The physical facilities and materials associated with optional excursion (such as pamphlets or statements) should be available and visually appealing. The equipments which were used in optional excursion should ensure safety and comfort for them and staff of optional excursion should have good appearance.

The overall optional excursion perceived quality has a negative mark (4.28) which means that there is a notable gap between excursionist expectations and perceptions ofoptional excursions. These results indicated that the level of quality that excursionists receive is lower than what they expect.

The test result in table 4 explained the relationship between excursionist expectations and perceptions of optional excursions. The p-value $<(0.05)$ for all dimensions which means that there is a high significant correlation between excursionist expectations and perceptions of optional excursions. Thus, the hypothesis (H1) is accepted for all the dimensions which mean that there is a notable gap between excursionist expectations and perceptions of optional excursions. Moreover, there is a significant difference between expectations and perceptions of optional excursions in all dimensions of Servqual (tangibles, reliability, responsiveness, assurance and empathy).

Table 4 Perceived quality of optional excursions dimensions

\begin{tabular}{|c|c|c|c|c|c|c|c|}
\hline Dimension & $\begin{array}{c}\text { Perception } \\
\text { Means }\end{array}$ & $\begin{array}{c}\text { Expectation } \\
\text { Means } \\
\tilde{\Xi}\end{array}$ & $\begin{array}{c}\text { Gap } \\
\text { Mean } \\
\tilde{\Xi}\end{array}$ & $\begin{array}{c}\text { Sig. } \\
\mathbf{\Xi}\end{array}$ & \\
\hline $\begin{array}{c}\text { Tangibles } \\
\text { (Q1-Q4) }\end{array}$ & 3.4931 & $\mathbf{2}$ & 4.3009 & $\mathbf{5}$ & -.8078 & $\mathbf{1}$ & 0.00 \\
\hline $\begin{array}{c}\text { Reliability } \\
\text { (Q5-Q9) }\end{array}$ & 3.4639 & $\mathbf{3}$ & 4.3222 & $\mathbf{3}$ & -.8583 & $\mathbf{3}$ & 0.00 \\
\hline $\begin{array}{c}\text { Responsivene } \\
\text { ss } \\
\text { (Q10-Q13) }\end{array}$ & 3.5243 & $\mathbf{1}$ & 4.3414 & $\mathbf{2}$ & -.8171 & $\mathbf{2}$ & 0.00 \\
\hline $\begin{array}{c}\text { Assurance } \\
\text { (Q14- Q17) }\end{array}$ & 3.4363 & $\mathbf{4}$ & 4.3507 & $\mathbf{1}$ & -.9144 & $\mathbf{5}$ & 0.00 \\
\hline
\end{tabular}




\begin{tabular}{|c|c|c|c|c|c|c|c|}
\hline Dimension & $\begin{array}{c}\text { Perception } \\
\text { Means }\end{array}$ & 前 & $\begin{array}{c}\text { Expectation } \\
\text { Means }\end{array}$ & 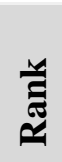 & $\begin{array}{c}\text { Gap } \\
\text { Mean }\end{array}$ & 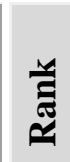 & Sig. \\
\hline $\begin{array}{l}\text { Empathy } \\
\text { (Q18-Q22) }\end{array}$ & 3.4204 & 5 & 4.3019 & 4 & -.8815 & 4 & 0.00 \\
\hline $\begin{array}{c}\text { Perceived } \\
\text { quality }\end{array}$ & & & & & -4.28 & & \\
\hline
\end{tabular}

\section{Conclusions}

Tremendous growth in the tourism sector has made this industry the third most important economic sector in Egypt's gross domestic product.Travel agent plays an important role in offering optional excursion asit has an incredible energy which impact and direct tourist demand. Optional excursion is one of the main tourism products in Egypt; and has become a niche market to the country.

Optional excursions are added to increase the attractiveness of the accommodation product with the aim of being attracting guests at first and possibly induce them to stay longer and spend more. Excursions can also be the main appeal of the vacation where accommodation itself (the lodge or the hotel) plays a secondary role such as many tourists visit Red Sea mandatory for diving.

This paper provides an evaluation for the quality of optional excursions in Hurghada city by employing SERVQUAL instrument that is used to measure a service quality based on the difference between consumers' expectations and perceptions of service. Quantitative approach based on a questionnaire was developed and directed to tourists when they practice optional excursions in Hurghada to achieve the aim of this study. The random sample size was 350 tourists.

Descriptive statistical analysis was used to investigate the socio demographic profile of the respondents. Paired t-tests were conducted to assess the significance of differences between the two means of expectations and perceptions at a significance level of $\mathrm{p}<0.05$.

Results indicated that snorkeling was the most popular type of optional excursion at Hurghada city by $22.7 \%$ of respondents. It is followed by $19.9 \%$ of respondents who practiced diving, then jeep safari which represents $19.4 \%$ of respondents. Next was beach buggy which ranked fourth by a percentage of $18.5 \%$ of respondents. The last one was water sports which represent $18.1 \%$ of respondents. 
There is significant difference between excursionists' perceptions and their expectations of optional excursions provided by travel agents in Hurghada. The quality level of expected services were greater than the actual quality level that excursionist received. The overall quality of optional excursions is low (-4.28) which means that the quality level of optional excursions that excursionists received is lower than what they expect.

The main findings of the research are that the average means scores for excursionist's expectations were higher than scores for excursionist's perceptions. The results indicated that all gaps between excursionist's expectations and perceptions of optional excursions quality have negative marks. It also indicates that the excursionists' expectations of optional excursion were not met.

It must be noted that all the expectation scores in relation to the service attributes in this study were higher than the perception scores, indicating that each service attribute suffered a service quality shortfall. According to Kang et al, (2002), the research on measuring service quality has focused primarily on how to meet or exceed the external customer's expectations and has viewed service quality as a measure of how the delivered service level matches consumer's expectations.

The largest gap mean was found for the staff of travel agency that were consistently courteous with excursionist (Gap mean=-94), and travel agencies have staff who give excursionist personal attention (Gap mean= $-94)$.

\section{RECOMMENDATIONS}

Travel agents managers in Hurghada have to improve the quality of optional excursions to reach the customer satisfaction without reducing prices to maintain the quality level of optional excursions. They have to diversify several excursion programs to attract more tourists and implement the promised programs accurately. They have to build competitive advantage against competitors.

They also have to point out the areas of weakness and try to strengthen it and give more attention to complaints. Travel agencies also have to implement strategies for human resources in short and long terms to recruit, train and develop qualified employees. Besides, tourism faculties and academic institutes must develop their educational programs and courses according to market needs and requirements accomplishing quality approach regarding international levels. 
Regarding the recommendations for the Egyptian government, they have to upgrade the infrastructure of the places where the optional excursions were carried out. They have to determine the capacity of the areas in which optional excursion are implemented and also secure these places and supply them with ambulance units.

\section{REFERENCES}

Ashley, C. (2005). "Developing local excursion for tourists". Brief no 5. Available at: http://www.odi.org/search/site/developing\%20local\%20excursions\% 20for\%20tourists, accessed on 20 Sep, 2016.

Biggs, D., J. et al. (2011). "The Value of Avitourism for Conservation and Job Creation- An Analysis from South Africa". Conservation and Society.

Boersma, I (2010). "Magical Egypt" available at: https://books.google.com.eg/books?id=dj4O91WKJisC\&printsec=fro ntcover\&dq=magical+egypt\&hl=en\&sa $=X \& v e d=0$ ahUKEwjo76eE0 K3aAhURLlAKHVp9AagQ6AEIJTAA\#v=onepage \&q=magical $\% 20$ egypt\&f=false, Accessed on June, 2016.

Buckles, G., (2007). "Dive the red sea" available at: https://books.google.com.eg/books?id=TzMDZWRG6QwC\&printsec $=$ frontcover $\&$ dq $=$ Dive + in + the + red + sea $\&$ hl $=$ en $\&$ sa $=X \& v e d=0 a h U K$ EwiJnZmppK_aAhWF7RQKHRW4DwAQ6AEIKjAB\#v=onepage\& q=Dive\%20in\%20the\%20red\%20sea\&f=false , accessed on SEP, 2017.

Butler, E., (2017). "Extreme water sports" available at: https://books.google.com.eg/books?id=LzLaDgAAQBAJ\&printsec=f rontcover\&dq $=\% \mathrm{E} 2 \% 80 \% \mathrm{~A} 2 \% 09 \mathrm{Butler}++\mathrm{Ex}$ treme + water+sports\&h l=en\&sa=X\&ved=0ahUKEwieh87jqa aAhWDBywKHRX7DpoQ6A EIJTAA\#v=onepage \&q=\%E2\%80\%A2\%09Butler\%20\%20Extreme \%20water\%20sports\&f=false , accessed on SEP, 2017.

Caruana, A. (2002). "Propositions and a Model: Do Excellemt Market Oriented Firms Who Deliver Quality Service Perform Better?". Management Research New, 18 (1/2), 9- 23, Retrieved April 6, 2015, from Emerald Insight Database.

Curtin, S., and Wilkes, K. (2007). "Swimming with Captive Dolphins: Current Debates and Post-experience Dissonance" International journal of tourism research Int. J. Tourism Res. 9, pp. 131-146 Retrieved May, 2016, from Wiley Inter Science www.interscience.wiley.com. 
Chang, J C. (2008). "Taiwanese Touristse perceptions of Service Quality on Outbound Guided Package Tours: A Qualitative Examination of the SERVQUAL Dimensions" Journal of Vacation Marketing, Volume 15(2), pp.164- 178, Retrieved Jan, 2017.

ETA, Egyptian Tourism Authority, (2015). "Egypt: Red Sea and Sinai: the most important tourism areas and resorts", Cairo, PP 10-11, 1417, 20-27. (In Arabic).

Friedland, L., et al. (2010). "Frommer,s 500 Adrenaline Adventures", Willey Publishing, USA.

Grönroos, C. (2007). "Service Management and Marketing: Customer Management in Service Competition", 3rd Edition, John Wiley \& Sons Ltd., England.

Hobbs, J, andFujiyo, T., (2007). " Soft Sedentarization: Bedouin Tourist Stations as a Response to Drought in Egypt's Eastern Desert"published on line at Springer Sciencepp 35:209-222, Accessed on Jul, 2015.

Horner, S., Swarbrook, J. (2004). "International cases in tourism management", Available at: https://books.google.com.eg/books?id=OwssBgAAQBAJ\&pg=PA10 $6 \& \mathrm{dq}=$ camel+riding+tourism\&hl=en\&sa=X\&redir_esc=y\#v=onepag e\&q=camel\%20riding\%20tourism\&f=false, accessed on: 20 Oct 2016.

Jafari, J (2002). "Encyclopedia of Tourism", p 213, Available at: https://books.google.com, Accessed on FEB, 2017.

Jennings, G., (2007). "Water-Based Tourism, Sport, Leisure, and Recreation Experiences" available at: https://books.google.com.eg/books?id=OQ8QEqC401QC\&printsec=f rontcover \&dq $=$ WaterBased+Tourism,+ Sport,+ Leisure,+ and + Recreati on++Experiences\&hl=en\&sa=X\&ved=0ahUKEwjNoeDhq6_aAhVR C-wKHTprB0cQ6AEIJTAA\#v $=$ onepage $\& q=$ Water-

Based\%20Tourism\%2C\%20Sport\%2C\%20Leisure \%2C\%20and\%20 Recreation\%20\%20Experiences\&f=false, Accessed on Nov, 2016.

Jones, L., (2008). "The Tourist Submarine Business", U.S. Submarines, Inc, U.S. PP. 6, 11-12, 20, Available at: http://www.ussubmarines.com/submarines/touristsubs.pdf , Accessed on: $18 \mathrm{Feb}, 2016$.

Jordan, M., (2000). "Ecological Impacts of Recreational Use of Trails: a Literature Review", P. 1, The Nature Conservancy, Cold Spring Harbor, New York, Available at: http://www.parks.ca.gov/pages/795/files/ecologicalimpactsrecreation alusers.pdf , accessed on: 11 Nov, 2014. 
Kandampully, J. (2000). " The Impact of Demand Fluctuation on the Quality of Service: a Tourism Industry Example", Managing Service Quality, 10 (1), 10-18, Retrieved April 6, 2015, from Emerald Insight Database.

Kvist, A. K. J. \& Klefsjo, B. (2006). "Which service quality dimensions are important in inbound tourism?" A case study in a peripheral location, Managing Service Quality, 16 (5), 520- 537, Retrieved June, 2015, from Emerald Insight Database.

Lam, T. \& Zhang H. (1999). "Service quality of travel agents: the case of travel agents in Hong Kong", Tourism Management, Vol. 20, No. 3, pp.341- 3 .

Mancini, M (2012). "Conducting tours: A practical guide", p.10, Available at: https://books.google.com, accessed on: Feb, 2017.

Manning, T., (2006). "Managing Cruise Ship Impacts: Guidelines for Current and Potential Destination Communities", pp. 1, 5, 9- 13, Available at: http://www.tourisk.org/content/projects/Managing\%20Cruise\%20Shi p\%20Impacts.pdf, accessed on: 30, Oct, 2015.

Moss, S. (2004). "A Bird in the Bush: A Social History of Bird watching". London: Aurum.

Musa, G., and Dimmock, K., (2013). "Scuba Diving Tourism", 1st, Routledge, USA, n. a, Available at: http://books.google.com.eg/books?id=xVOZrTFF5ykC\&pg=PT23\&d $\mathrm{q}=$ types+of+diving \&hl=ar\&sa=X\&ei=69LCUunhJ6un0wXYqYDwD Q\&redir_esc $=\mathrm{y} \# \mathrm{v}=$ onepage \&q=types\%20of\%20diving\&f=false Accessed on: 15 Oct, 2016.

PADI, Professional Association of Diving Instructors, (2013). "Mooring Buoy Planning Guide", p.12, available at: https://books.google.com/books/.../Mooring_Buoy_Planning_Guide. html, accessed on: 5 Nov, 2014.

Pastiu, C. et al. (2014). "The role of travel agencies in tourism development in Alba country", pp 328-329. Available at: https://ideas.repec.org/p/tho/iscthi/section5-4.html, accessed on JAN, 2017.

Red Sea Governorate, (2015). "The Red Sea Governorate", Available at: http://www.redsea.gov.eg/tourism/default.aspx, accessed on: 7 Nov. 2015.

Shahin, A, (2004). "SERVQUAL and model of service quality gaps: A framework for determining and prioritizing critical factors in delivering quality services". Paper presented at the International Conference, Tehran, Iran. 
UNWTO, United Nations World Tourism Organization, (2014). "Towards measuring the economic value of wildlife watching tourism in Africa, Available at: https://sustainabledevelopment.un.org/content/documents/1882unwto wildlifepaper.pdf, accessed on Jan, 2017.

USAID, United States Agency for International Development (2004). "Ecotourism Development in the Southern Red Sea Region".

Yoon, T_H \& Ekinci, (2003). "An Examination of the SERVQUAL Dimensions Using the Guttman Scaling Procedure", Journal of Hospitality \& Tourism Research, 27 (1), Retrieved May 19, 2015, from Sage Publications Database. 